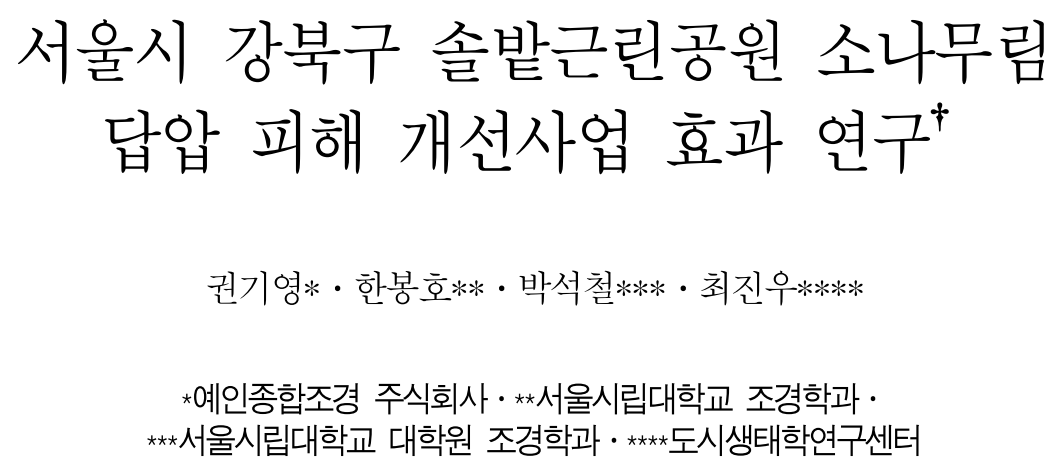

\title{
The Improvement Effect of Pinus densiflora Forest Disturbed by Human Trampling in the Solbat Neighborhood Park, Gangbuk-gu, Seoul
}

\author{
Kwon, Ki-Young* $\cdot$ Han, Bong-Ho** Park, Seok-Cheol ${ }^{* \star *} \cdot$ Choi, Jin-Woo ${ }^{* \star * *}$ \\ *Ye In Total Landscape Architecture Co., Ltd. \\ **Dept. of Landscape Architecture, University of Seoul \\ ${ }^{* * *}$ Dept. of Landscape Architecture, Graduate School, University of Seoul \\ ****Urban Ecology Research Center
}

\begin{abstract}
The purpose of this study is to validate the effect of improvement such measures as fence installation or planting of bush and herbaceous plants taken from Pinus densiflora forest in Solbat Neighborhood Park in Seoul, which was damaged by stamping. The study was conducted in 2005 and 2010 in order to analyze changes in planting types, planting structure of Pinus densiffora forest, soil hardness, cross-sectional structure of soil, and physicochemical characteristics of soil. It was also measured by the growth of the branches and the diameter of Pinus densiffora, comparing before and after the improvement to study the effect of restoring Pinus densiflora forest damaged by stamping. When it comes to a change in planting type, Pinus densiffora forest without underlay was reduced from $48.5 \%$ in 2005 to $6.8 \%$ in 2010 . Pinus densiffora forest with bush and herbaceous plants was increased dramatically from $7.4 \%$ to $46.8 \%$. Regarding planting structure, in most area of the subject site, Pinus densiffora forest without under layer was transformed into the one with bush and herbaceous plants including Rhododendron mucronulatum, Rhododendron schippenbachii, Hemerocallis fulva, Aceriphyllum rossii, Hosta plantaginea growing in a wide area. The soil in the Solbat Neighborhood Park was very stiff with soil hardness of $54.8 \mathrm{~kg} / \mathrm{cm}^{2}$ in average. After the improvement efforts made in the Park in 2010, the soil hardness was mostly less than $4 \mathrm{~kg} / \mathrm{cm}^{2}$, being in a good condition with little influence on the growth of plants. When it comes to the cross-sectional structure of soil, litter layer didn't exist in 2005 because of stamping and the organic matter layer was only $1.0 \mathrm{~cm}$ thick, which provided an unfavorable condition for plant growth. However, after improvement, litter layer was formed up to $3.0 \mathrm{~cm}$ and thickness of the organic matter layer also went up to $1.5 \sim 8.0 \mathrm{~cm}$ in 2010 because the damage from stamping was reduced. Concerning the physicochemical characteristic of soil, in 2005 soil showed $\mathrm{pH} 5.76 \sim 6.70$, organic matter content $7.15 \sim 10.55 \%$, and
\end{abstract}

\footnotetext{
${ }^{\dagger}$ : 이 논문은 저자의 석사학위논문 결과를 발전시킨 것임.

Comesponding author: Ki-Young Kwon, Ye In Total Landscape Architecture Co., Ltd., Seoul 138-220, Korea, Tel.: +82-22210-2592, E-mail: rnis4394@chollian.net
} 
available phosphorus $9.38 \sim 26.47 \mathrm{mg} / \mathrm{kg}$, having no big problems as a soil environment for growth of Pinus densiflora. 15 trees of Pinus densiflora were selected to see branch growth and it was found that the branches tended to grow better after improvement. 70 trees of Pinus densiflora from various grades of soil hardness also were selected to identify changes of diameter growth. In most cases, it was analyzed that Pinus densiflora grew better after improvement. After conducting this study, it was validated that such measures as fence installation or planting of bush and herbaceous plants to restore Pinus densiflora Forest damaged by stamping were effective in improving growth of Pinus densiflora.

Key Words: Planting Structure, Soil Hardness, Cross-Sectional Structure of Soil, Growth of Branches, Growth of Diameter

$$
\text { 국문초록 }
$$

본 연구의 목적은 서울시 솔밭근린공원 소나무림을 대상으로 울타리 설치, 관목 및 초본식물 식재 등의 답압 피해 개선사업의 효과를 검증하는 것이다. 2005년과 2010년 현장조사를 통해 소나무 식재유형, 식재구조, 토양경도, 토양단면구 조, 토양 이화학적 특성 등의 변화 상태를 분석하였다. 또한 소나무의 가지생장량과 직경생장량을 측정하여 개선사업 전과 후 상태를 비교 - 분석하여 답압 피해지역 개선사업에 따른 효과를 고찰하였다. 식재유형 변화에서는 하층 식생이 없는 소나무림이 2005년 48.5\%에서 2010년에는 6.8\%로 감소하였으며, 관목 및 초본이 식재된 소나무림이 $7.4 \%$ 에서 $46.8 \%$ 로 크게 증가하였다. 식재구조 변화에서는 대부분 조사구가 하층식생이 거의 없는 소나무림에서 진달래, 철쭉꽃, 원추리, 돌단풍, 옥잠화 등 관목 및 초본식생이 넓게 피복된 소나무림으로 변화되었다. 2005년 솔밭근린공원의 토양경도는 평균 $54.8 \mathrm{~kg} / \mathrm{cm}^{2}$ 로 딱딱한 토양층이었다. 2010년 솔밭근린공원 개선사업 후 토양경도는 대부분 $4 \mathrm{~kg} / \mathrm{cm}^{2}$ 미만으로 식물생육에 영향이 없는 양호한 상태였다. 2005년에 토양단면구조는 답압 영향으로 인해 낙엽층이 소실되어 있었으며, 유기물층이 $1.0 \mathrm{~cm}$ 로 식물이 생육하는데 적합하지 않았다. 개선사업 후 2010 년에는 답압에 대한 피해가 줄어서 낙엽층이 $3.0 \mathrm{~cm}$ 까지 새롭게 형성되었고, 지속적인 시비에 따라 유기물층의 깊이도 $1.5 \sim 8.0 \mathrm{~cm}$ 로 증가하였다. 2005년 토양 이화학적 특성에서는 $\mathrm{pH} 5.76 \sim 6.70$, 유기물 함량 7.15 10.55\%, 유효인산 9.38 26.47mg/kg으로 소나무 생육 토양환경조건으로 큰 문제가 없었 다. 또한 소나무 15 주를 선정하여 가지생장량을 분석한 결과, 개선사업 이후 가지생장량이 점차 증가하는 경향이었다. 토양경도 등급에 따라 소나무 70주를 선정하여 직경생장량을 측정한 결과, 대부분 조사구에서 소나무가 개선사업 이후 생육이 양호해지는 것을 확인할 수 있었다. 본 연구결과를 통해 울타리 설치, 관목 및 초본식물 식재 등의 답압 피해 개선사업이 소나무 생장을 향상시키는 효과를 검증할 수 있었다.

\section{주제어: 식재구조, 토양경도, 토양단면구조, 가지생장량, 직경생장량}

\section{I. 서론}

소나무(Pinus densiffora S. et Z.)는 한반도, 일본, 중국의 산 동반도, 백두산 동북부 지역에 분포하는 침엽(針葉)수종으로 수평적으로 북위 $30^{\circ} 20^{\prime} \sim 46^{\circ}$ 사이의 온대 및 아한대지역에 분 포한다(이창복, 1980). 소나무의 생육은 입지환경과 연관성이 높으며, 모든 방위에서 분포하나 일반적으로 남향이나 서향보 다는 북향이나 동향에서 생장이 양호하며, 지형별로는 상승사 면보다 하강사면에서 생장이 양호한 편이다. 산복(山腹)에서 산정(山頂)으로 갈수록 생장이 불량한 것은 지형 특성상 토양 수분조건이 생장 제한요인으로 작용하기 때문이다. 소나무는 건조하고 임지비옥도가 낮은 능선 사면부나 침식이 발생된 나 지 등에서도 잘 적응하여 생육할 수 있으나, 이들 지역이 소나
무의 생장적지라는 의미는 아니며, 산록(山麓)이나 계곡부의 양분이나 수분조건이 좋은 곳에서도 양호한 생육상태를 보인 다. 하지만 과습한 지역에서는 통기성 불량에 의한 뿌리호흡 문제가 발생하여 생육상태가 불량하다(임업연구원, 1999). 소 나무는 통기가 양호하고 비교적 건조하며 양분이 적고 산성이 강한 토양이 적합하고(吉岡, 1958), 심근성이나 측근도 잘 발달 하고 온도와 수분에 폭넓은 적응성을 가지고 있다(이우철과 이 철환, 1989). 기존의 소나무 생육상태 연구는 주로 도시지역과 공단지역에서 토양 오염에 따른 소나무 생육에 관한 연구(이창 석, 1993; 이창석 등, 1998), 기후인자와 소나무 생장과의 연구 (이상태 등, 2005; 정연숙, 1995), 토양산성화와 소나무 생장과 의 연구(진현호 등, 2008; 이충화 등, 2002; 이도형, 2004; 이승 우 등, 2008) 등이 진행되었다. 서울시 소나무림을 생태적 특성 
에 따라 분류한 결과(이수동 등, 2009), 소나무순림에 속하는 토지극상림(26.1\%)과 소나무순림(21.5\%), 소나무와 타수종이 경쟁하는 소나무-신갈나무림(28.0\%), 소나무-리기다소나무림 (13.1\%), 소나무-상수리나무림(4.2\%) 등으로 구분되었다. 이 들 유형에 대한 정밀한 식생조사 결과, 토지극상, 답압 피해, 식 생관리로 인해 교목층과 하층에 경쟁종이 출현하지 않아 소나 무림 유지가 가능한 4 개 군집은 하층식생 보완 등 소극적인 관 리가 필요하였다.

서울시 강북구 소나무림은 삼각산을 중심으로 $828,304 \mathrm{~m}^{2}$ 면 적으로 분포하고 있는데, 삼각산을 끼고 있는 다른 자치구인 은 평구 $\left(4,109,740 \mathrm{~m}^{2}\right)$, 종로구 $\left(3,974,253 \mathrm{~m}^{2}\right)$, 성북구 $\left(1,932,051 \mathrm{~m}^{2}\right)$ 보다 소나무림 면적이 협소한 반면에 수유동 일대를 중심으로 우량한 대경목 소나무가 잔존하고 있어 지속적인 보전이 요구 되고 있다. 그 중 솔밭근린공원은 서울시에서 유일한 평지형 소나무림으로 강북구 주민 및 북한산국립공원 탐방객들이 즐 겨찾는 소나무림이다(강북구, 2005).

솔밭근린공원은 개원 이후 이용객이 급증하면서 심한 답압 이 발생되어 소나무의 뿌리 피해가 발생하게 되었다. 식물이 답압 등에 의하여 토양의 견밀화가 진행되면 지하부 뿌리 발달 이 지장을 받아 지상부의 엽량 감소나 생장 감소로 이어지게 된다. 이후 진행이 가속화 되면 가지나 초두부가 시드는 등의 가시적인 수목 쇠퇴 증상이 나타나게 되며, 답압의 강도가 커 질수록 불건전한 수목이 더욱 늘게 된다(이승우, 2005). 또한 숲길에서 답압 피해는 난투수층 형성, 식물의 직-간접 손상, 나지의 확대로 이어진다(오광인과 정남철, 1998; 김태호, 2003; 최오길, 2002). 조현길 등(2011)은 강원도 영서지역 소나무 마 을숲을 대상으로 소나무 숲의 생장저해를 야기하는 주 요인으 로 양분 부족, 복토 및 답압, 수간 훼손, 병충해 등을 제시하였 고, 관리방안으로 유기물과 석회 사용, 복토 제거, 토양 굴기(屈 ⿺ㄹㄹ)와 자갈 포설, 목도 설치 또는 우드칩 포장, 목책 및 보호틀 제공, 수간 외과수술, 수세강화, 수간주사 등 생장환경을 개선 하거나 수간훼손과 병충해를 제어할 대책을 제시하였다.

본 연구는 서울시 강북구 솔밭근린공원의 소나무림 개선사 업 시행에 따른 소나무 생육상태의 변화를 조사하기 위하여 답 압 피해가 발생되었던 2005년과 2007년, 개선사업 후 3년이 경 과된 2010년의 소나무 생육상태를 조사 - 분석하였다. 본 연구 는 솔밭근린공원 내 소나무가 인간의 간섭(답압)과 개선사업 에 따른 소나무 생육상태 변화에 주안을 두고 있다. 연구결과 는 시민이용이 과도한 녹지 지역에 대한 관리 및 개선사업의 효과를 검증하여 무분별한 이용을 통제하고, 녹지의 지속가능 한 유지 관리 방향을 제시하고자 하였다.

\section{II. 연구 방법}

\section{1. 연구대상지}

솔밭근린공원은 서울시에서 유일한 평지형 소나무림으로 1980 년대 말 지역주민과 강북구청의 노력으로 아파트 건설계획을 철회하여 소나무림으로 보존한 지역이다. 그 후 1996년 근린공 원으로 지정되었고, 1998년 7월 근린공원조성계획이 수립되어 2004년 1월 솔밭근린공원으로 개원하였다(그림 1 참조). 솔밭 근린공원에는 소나무 하부 산책로뿐만 아니라 예술마당, 노송 마당, 진입마당, 문화놀이마당, 배드민턴장, 장기마당, 어린이놀 이터 등의 시설지가 갖추어져, 지역주민들의 휴식, 운동, 만남, 산책 등이 이루어지고 있다. 공원 개원 후 야외소풍, 사생대회, 지역행사뿐만 아니라 삼각산 문화와 관련된 4월 진달래축제, 10 월 삼각산축제 등 각종 문화행사 개최지로 강북구의 핵심적 인 지역문화공간으로 자리매김되어 왔다. 또한 솔밭근린공원 은 향후 소나무 보존 및 환경친화적인 이용의 잠재성이 높은 곳이다.

하지만 솔밭근린공원은 이용객이 급증하게 되어 소나무림 하 부의 무분별한 답압으로 인해 소나무 뿌리 피해가 발생하였고, 대규모 행사 개최에 따른 쓰레기 및 소음 발생, 소나무 훼손 등 지역주민들과 공원관리자들로부터 많은 문제점이 제기되어 왔 다. 이에 2005년 9월 수유동 지역주민과 강북구청 공무원 중심 으로 소나무림 보호를 위한 민관협의체인 '솔밭공원을 사랑하 는 모임(솔사모)'를 결성하여 지속가능한 공원운영방안을 마련 하게 되었다. 이에 따라 2007년에는 목책 및 잔디보호책 설치, 초화류 식재와 같은 개선사업이 시행되었다. 이는 소나무림 내 부로 무분별하게 진입하는 동선을 제한하여 추가적인 토양 답

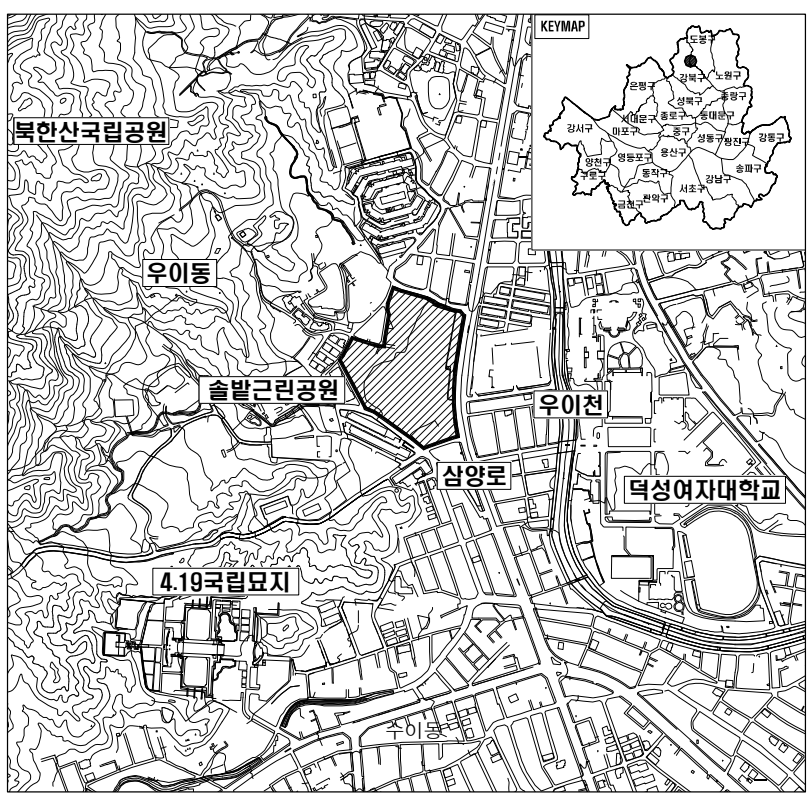

그림 1. 연구대상지 위치도 
압 피해를 방지하고자 하였다. 2009년에는 강북구청에서 솔밭 공원 자연학습생태체험장 조성사업으로 일부 지역에 생태연못 과 초화류 단지를 조성하였다.

본 연구는 솔밭근린공원의 답압 피해 개선사업의 효과를 검 증하기 위해 사업 전과 후 소나무림의 생태적 특성 변화, 토양 구조 및 특성 변화, 소나무 생육상태 변화를 분석하였다. 소나 무림의 생태적 특성 변화는 소나무 식재유형과 식재구조 변화 를 분석하였으며, 토양구조 및 특성 변화는 토양경도, 토양단면 구조, 토양 이화학적 특성 등의 변화를 분석하였다. 소나무 생 육상태 변화는 소나무의 가지생장량과 직경생장량을 분석하였 다. 이상의 분석 결과를 종합하여 소나무림의 답압 피해 개선 사업 효과를 도출하였다.

\section{2. 조사분석 방법}

\section{1) 식재유형 및 식재구조}

강북구 솔밭근린공원 소나무 식재유형도는 $1 / 1,000$ 수치지형 도를 이용하여 교목층 수종의 식생상관(Vegetational physiognomy) 과 하층식생 유형을 기준으로 2005년과 2010년에 각각 조사하 였다. 식재유형도는 Autocad Map 2004와 ArcView 3.3 프로그

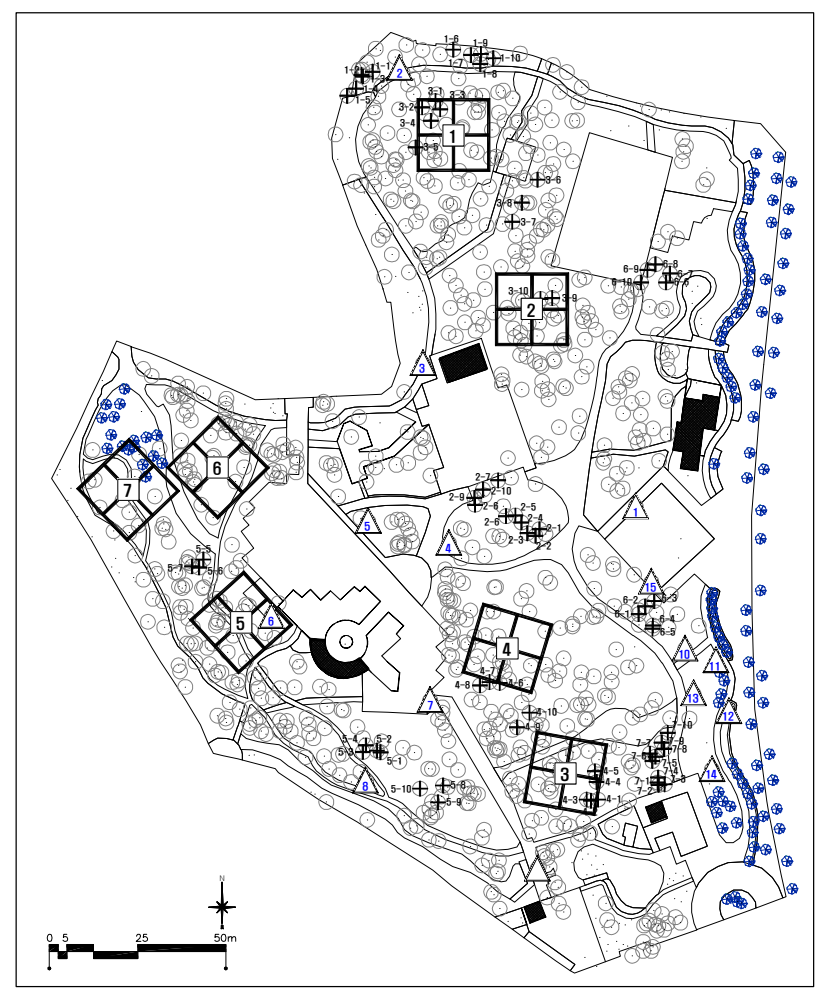

그림 2. 강북구 솔밭근린공원 소나무 식재구조 및 생육상태 조사구 위치도

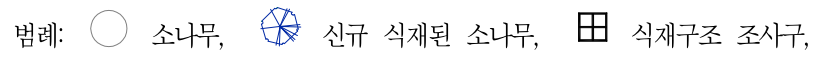
$\triangle$ 가지생장량 조사수목, $\rightarrow$ 직경생장량 조사수목
램을 이용하여 도면을 작성하였고, 식재유형별 면적비율을 산 출하였다. 식재구조는 솔밭근린공원 2005년 조사구 7개소를 대 상으로 2010년 동일한 조사구에 조사를 실시하여 비교·분석 하였다. 식재구조 조사구는 2005년 조사 당시 조사구 1 5는 하층식생이 거의 없는 소나무림으로 답압 피해가 심각한 지역 이었다. 조사구 6과 조사구 7은 상대적으로 답압 피해가 낮았 으며, 관목층으로 진달래 등이 울폐도 $20 \%$ 의 비율로 식재된 지역이었다. 식재구조 조사는 방형구법(Quadrat method)을 사 용하여 $20 \mathrm{~m} \times 20 \mathrm{~m}\left(400 \mathrm{~m}^{2}\right)$ 의 조사구를 설치하고, 수목 위치를 기록하였으며, 각 조사구 내에 출현하는 수종을 대상으로 흥고 직경 $2 \mathrm{~cm}$ 이상 수종의 흥고직경, 수고, 지하고, 수관폭을 조사 하였다(박인협, 1985). 관목층은 수고, 지하고, 수관투영면적을 조사하였으며, 조사내용을 토대로 답압 피해 개선사업 전과 후 를 비교·분석하였다(그림 2 참조).

\section{2) 토양특성}

토양경도는 야마나까(山中) 경도계를 이용하여 측정하고자 하는 부위의 토양을 수평이나 수직으로 표면이 아주 평평하게 파고 다듬은 후 경도계를 손에 단단히 잡고 유동지표를 0 에 맞 추고 토양에 직각으로 관입시키켰다. 유동지표가 가르키는 눈 금 $(\mathrm{mm})$ 을 정확히 읽고, 다음과 같은 계산공식으로 경도 $(\mathrm{R})$ 을 계산하였다(농업과학기술원, 2000). 2005년에는 소나무림(이용 지역), 소나무림(높이 $50 \mathrm{~cm}$ 이상 경계석으로 이용이 힘든 지 역), 소나무림(관목 및 초본식재지)으로 구분하여 측정하였고, 2010년에는 과거 조사지역을 대상으로 동일하게 측정하였다. 토양경도 $25 \mathrm{~mm}\left(15 \mathrm{~kg} / \mathrm{cm}^{2}\right)$ 이상에서는 작물의 뿌리발육이 좋 지 않으므로 경운하거나 관개하여 토양을 부드럽게 해주어야 한다(日本土壤物理性測定法委員會, 1972).

$$
\mathrm{R}\left(\mathrm{kg} / \mathrm{cm}^{2}\right)=100 \mathrm{X} / 0.795 \times(40-\mathrm{X}) 2
$$

\section{여기서, $\mathrm{R}=$ 토양경도 $\mathrm{X}=$ 유동지표가 가르키는 눈금}

토양단면구조 조사는 식재구조 7 개 조사구 $\left(400 \mathrm{~m}^{2}\right)$ 내에서 임 의의 지점을 골라 실시하였다. 토양단면구조는 식물의 근계발 달을 고려하여 낙엽층을 걷어내고, 수목의 세근이 발달하는 층 까지 수직으로 굴취한 뒤 낙엽층과 유기물층의 깊이를 측정하 고 사진촬영을 병행하였다. 본 연구에서는 토양 이화학적 특성 분석을 SSSA(Soil Science Society of America)의 Method of Soil Analysis를 준용하여 수행하였다. 토양시료 채취는 방형구 조사구 내에서 임의의 지점을 선정하여 $\mathrm{A} 0$ 층을 걷어내고, 표 층으로부터 토양을 채취 - 혼합하여 음건하였다.

3) 소나무 생육상태 
소나무는 유한생장하는 수종으로 정아가 줄기의 끝에 자리 잡고 줄기의 생장을 주도함으로써 한 가지당 1 년에 한 번 혹은 두세 번 정아가 차례대로 형성되면서 신장하는 특징을 가지고 있다. 또한 직경 생장은 주로 유관속 형성층의 활동에 의해 방 사생장으로 이루어지며, 사부 바깥쪽에 위치하고 있는 코르크 형성층도 비대생장에 일부 기여한다. 소나무 줄기의 횡단면에 매년 하나씩 형성되는 나이테는 세포 직경이 크고 세포벽이 얇 은 춘재와 세포의 직경이 작고 세포벽이 두꺼운 추재로 구성되 어 있는데, 전년도에 형성된 추재와 이듬해에 형성된 춘재 사 이에 뚜렷한 경계선이 만들어진다(김용식 등, 2006). 본 연구 에서는 이러한 소나무의 해부학적 특성을 바탕으로 가지생장 량과 직경생장량을 통해 대상지 내 소나무의 생장 현황을 판단 하였다. 가지생장량은 과거에서부터 현재까지도 사람들의 이용 으로 인해 답압 피해가 지속되고 있는 산책로 주변의 소나무 15 주를 선정하여 측정하였다(그림 2 참조). 조사수목에서 1년 생 가지, 2 년생 가지, 3 년생 가지, 4년생 가지, 5년생 가지, 6 년 생 가지를 대상으로 5 반복하여 가지길이 $(\mathrm{mm})$ 를 조사하였다. 최근 1 3년 사이의 가지생장량의 평균값과 답압 피해지 개선 사업을 시행하기 전 2004 2006년 소나무의 가지생장량 평균 값을 비교 - 분석하였다. 직경생장량은 토양경도 조사 결과를
바탕으로 7개 조사구(조사구 1: 0 10kg/cm ${ }^{2}$, 조사구 2: 10 $15 \mathrm{~kg} / \mathrm{cm}^{2}$, 조사구 3: $15 \sim 30 \mathrm{~kg} / \mathrm{cm}^{2}$, 조사구 4: $30 \sim 50 \mathrm{~kg} / \mathrm{cm}^{2}$, 조사구 5: 50 70kg/ $\mathrm{cm}^{2}$, 조사구 6: $70 ~ 100 \mathrm{~kg} / \mathrm{cm}^{2}$, 조사구 7: $\left.100 \sim 140 \mathrm{~kg} / \mathrm{cm}^{2}\right)$ 를 선정하여 조사구별로 10 주를 선정하여 총 70 주를 측정하였다(그림 2 참조). 목편 추출 부위는 지상 $1.2 \mathrm{~m}$ 되는 높이에서 생장추를 이용하였으며, 정확한 수령 파악을 위 하여 수(pith)를 관통하도록 하였다. 그리고 생장추를 활용하 여 뽑아낸 목편에서 $1 \mathrm{~cm}$ 내의 연륜수를 조사하여 수령을 조사 하고, 최근 생장량을 측정하였다. 소나무 생육상태 변화 검증은 통계분석 프로그램 SPSS 12.0 을 사용하여 대응표본 $T$-검정을 실시하였다.

\section{III. 결과 및 고찰}

\section{1. 생태적 특성 변화}

\section{1) 식재유형}

솔밭근린공원의 소나무림을 중심으로 식재유형을 비교 - 분 석한 결과(표 1 , 그림 3 참조), 개선사업 전과 후 가장 큰 변화 는 전체면적 $34,752 \mathrm{~m}^{2}$ 중 하층 식생이 없는 소나무림(나지)이

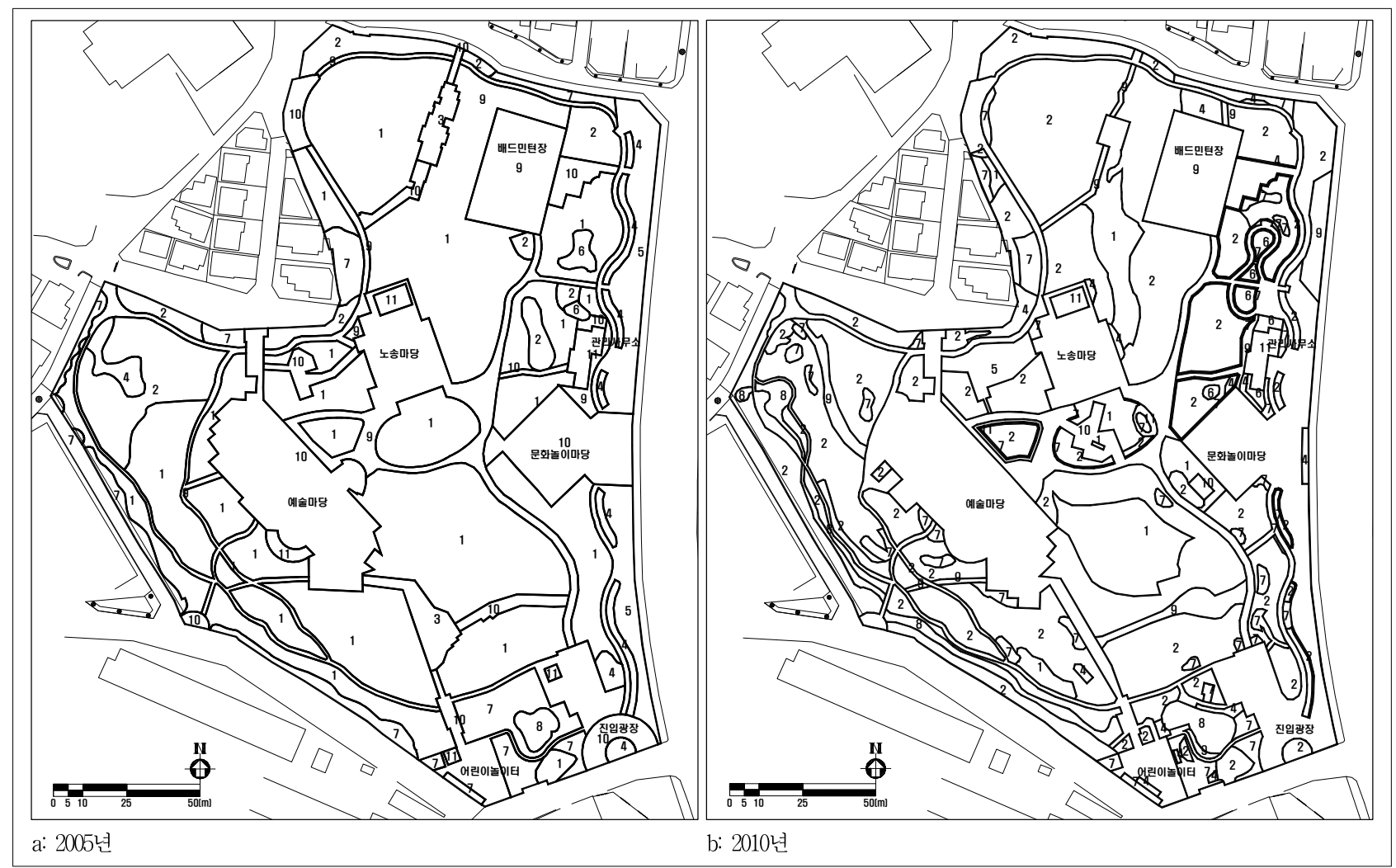

그림 3. 강북구 솔밭근린공원 소나무 식재유형 변화

범례: 1: 소나무림(나지), 2: 소나무림(관목 및 초본식재지), 3: 소나무림(불투수포장지), 4: 소나무식재지, 5: 소나무식재지(불투수포장지), 6: 상수리나무림, 7: 소나무식재지, 8: 수공간, 9: 나지, 10: 비건폐포장지, 11: 건폐지 
표 1. 강북구 솔밭근린공원 소나무 식재유형별 면적 및 비율 변화

\begin{tabular}{l|r|r|r|r}
\hline \multirow{2}{*}{ 구분 } & \multicolumn{2}{|c|}{ 면적 $\left(\mathrm{m}^{2}\right)$} & \multicolumn{2}{c}{ 비율(\%) } \\
\cline { 2 - 5 } & 2005 년 & 2010년 & 2005년 & 2010 년 \\
\hline 소나무림(나지) & 16,864 & 2,353 & 48.5 & 6.8 \\
\hline 소나무림(관목 및 초본식재지) & 2,587 & 16,270 & 7.4 & 46.8 \\
\hline 소나무림(불투수포장지) & 532 & - & 1.5 & - \\
\hline 소나무식재지 & 726 & 499 & 2.1 & 1.4 \\
\hline 소나무식재지(불투수포장지) & 1,861 & 362 & 5.4 & 1.0 \\
\hline 상수리나무림 & 143 & 209 & 0.4 & 0.6 \\
\hline 조경수식재지 & 1,893 & 1,776 & 5.4 & 5.1 \\
\hline 인공연못 & 146 & 764 & 0.4 & 2.2 \\
\hline 나지 & 4,063 & 1,940 & 11.7 & 5.6 \\
\hline 비건폐포장지 & 5,570 & 10,244 & 16.0 & 29.5 \\
\hline 건폐지 & 367 & 325 & 1.1 & 0.9 \\
\hline & 34,752 & 34,741 & 100.0 & 100.0 \\
\hline
\end{tabular}

2005 년 48.5\%에서 2010년에는 6.8\%로 감소하였으며, 소나무림 (관목림 초본식재지)은 $7.4 \%$ 에서 $46.8 \%$ 로 크게 증가하였다. 소나무 식재지는 $2.1 \%$ 에서 $1.4 \%$ 로, 불투수 포장지에 식재된 소 나무 유형은 $5.4 \%$ 에서 $1.0 \%$ 로 감소하였다. 상수리나무림, 조 경수식재지, 건폐지의 비율은 거의 유사하였고, 인공연못의 비 율이 증가하였다. 또한 기존 소나무식재지(불투수포장지)와 나 지 유형이 비건폐포장지로 전환되어 비건폐포장지가 $16.0 \%$ 에 서 $29.5 \%$ 로 증가하였다.

\section{2) 식재구조}

7개 조사구는 대경목 저밀도 소나무림으로 평균 수고 $15 \mathrm{~m}$, 평균 흥고직경 $30 \mathrm{~cm}$, 울폐도 $80 \%$ 로 자연상태의 정상적인 소 나무림 교목층 구조를 형성하고 있었다. 2005년 조사 당시 7개 조사구 중 조사구 1 5는 하층식생이 거의 없는 소나무림으로

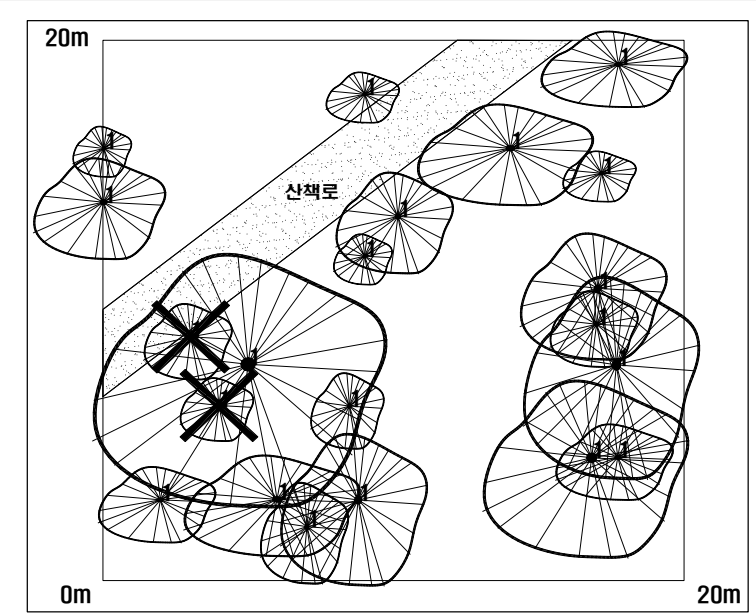

a: 조사구 3(2005년)

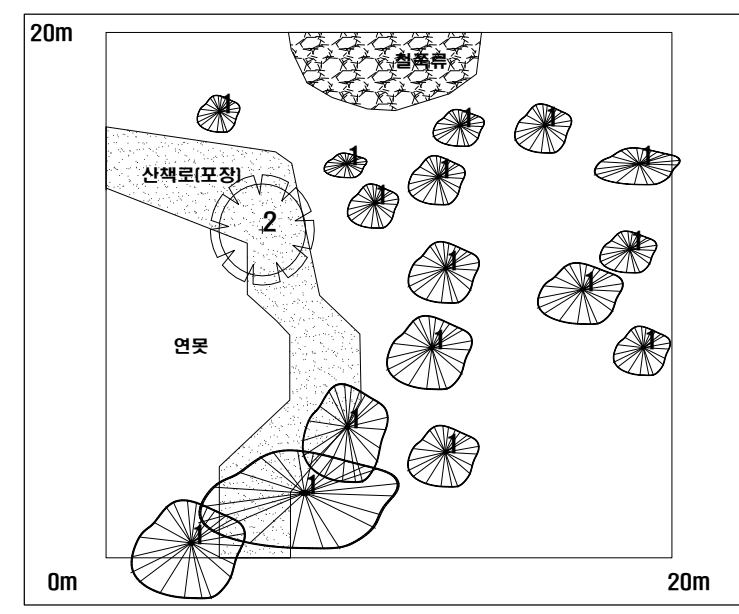

c: 조사구 $7(2005$ 년 $)$

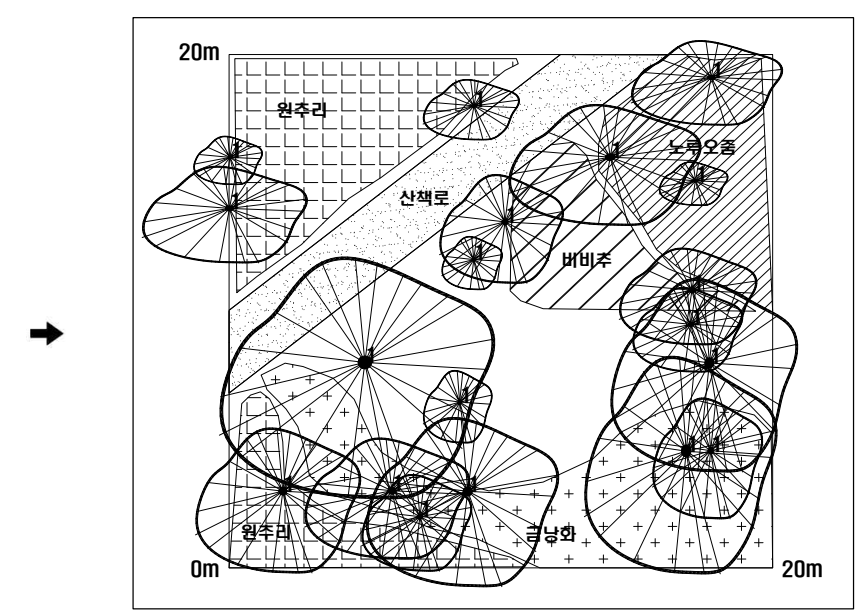

b: 조사구 3(2010년)

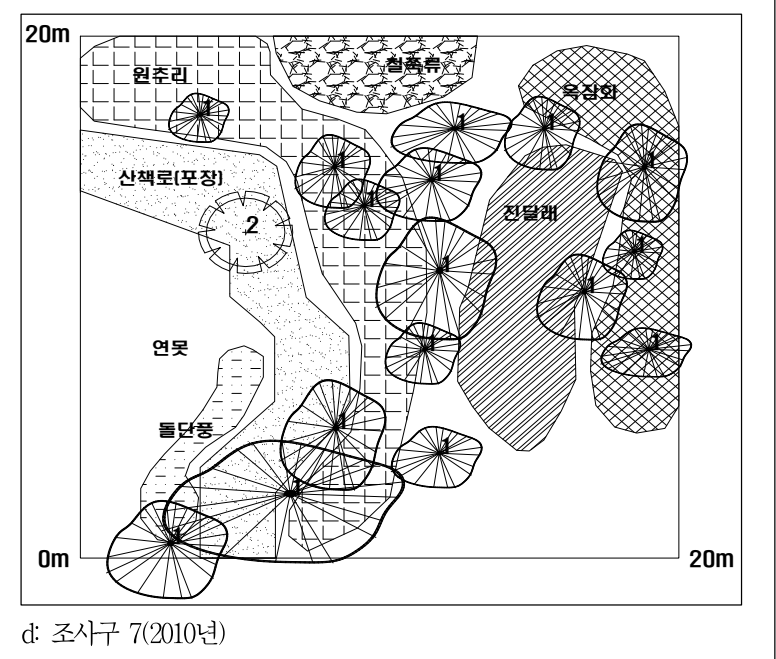

그림 4. 강북구 솔밭근린공원 소나무 식재구조 수관투영 변화

범례 1 소나무, 2 벚나무, $X$ 고사 
답압 피해가 심각한 지역이었으며, 조사구 6 7은 답압 피해를 받고 있었지만 상대적으로 피해가 낮으며 관목층으로 진달래 등이 울폐도 $20 \%$ 의 비율로 생육하고 있었다.

그림 4 는 조사구 3 과 조사구 7 의 수관투영 변화를 나타낸 것 으로 과거 소나무림 나지 지역으로 소나무 교목층 이외의 식생 은 없는 지역이었다. 조사구 3의 2005년과 2010년의 식재구조 변화를 살펴보면 소나무림이 생장하여 수관폭이 확대되었고, 그 중 소나무 2주가 대경목의 영향으로 고사하였다. 소나무 하부 에는 원추리, 비비추, 노루오줌, 금낭화가 피도 $54.8 \%$ 로 신규로 식재되어 있었다. 조사구 7의 2005년과 2010년의 식재구조 변 화를 살펴보면 생육변화에 따라 수관폭이 넓어졌고, 소나무 하 부에 진달래가 신규로 식재되었으며, 옥잠화, 돌단풍, 원추리가 조사구에 피도 $15.9 \%$ 로 신규 식재되어 있었다(그림 4 참조).

\section{2. 토양구조 및 특성 변화}

\section{1) 토양경도}

솔밭근린공원 개선사업 전과 후 토양경도 변화를 비교· 분 석하였다(표 2 참조). 이용변화가 높은 나지의 소나무림은 토 양경도가 평균 $54.8 \mathrm{~kg} / \mathrm{cm}^{2}$ 로 답압이 심한 토양층이었고, 높이 $50 \mathrm{~cm}$ 이상 경계석이 배치된 소나무림도 평균 $15.8 \mathrm{~kg} / \mathrm{cm}^{2}$ 로 토 양경도가 높았다. 관목 및 초본이 식재되어 접근이 제한된 소 나무림은 토양경도가 $5.5 \mathrm{~kg} / \mathrm{cm}^{2}$ 로 양호한 상태이었다. 토양경 도가 $15 \mathrm{~kg} / \mathrm{cm}^{2}$ 이상이면 토양의 통기성과 배수성이 불량해지 며, 유출수의 증가로 표토층의 양분이 유실된다. 또한 토양의 비옥도가 저하되어 수목의 뿌리가 정상적으로 생장하지 못하 므로(대한주택공사 주택연구소, 2000) 답압에 대한 대책이 필
요하였다. 조현길 등(2011)은 강원도 영서지역 소나무 마을숲 의 토양경도가 높은 지역에 대해 토양을 굴기(屈起)하고, 자갈 을 포석, 보행동선에는 목도 설치, 우드칩 포장 등을 통해 답압 및 나지화를 방지해야 한다고 하였다.

강북구 솔밭근린공원은 2005년 2007년에 답압 피해 개선사 업으로 소나무림 식재지 대부분에 울타리를 설치하고, 초화류 를 식재하여 접근을 제한하였다. 2010년 토양경도 조사결과, 대 부분 지역에서 $4 \mathrm{~kg} / \mathrm{cm}^{2}$ 미만으로 양호한 상태로 개선되었다. 초화류 식재사업은 식재시 답압으로 딱딱해진 토양을 경운하 는 과정을 거치게 되며, 이용자의 진입을 제한함으로써 소나무 림 토양환경 개선 및 생육상태 증진에 많은 도움을 준 것으로 판단되었다. 도시녹지 특히 공원의 경우 그 곳에 분포하는 식 생 형태에 따라 답압의 주원인인 이용자 왕래 빈도가 매우 다 르다. 이용에 의한 식생 변화는 토양답압의 영향과 밀접한 관 련이 있으므로 사전에 이용자 통제를 통한 토양관리가 필요하 다(이승우, 2005).

\section{2) 토양단면구조}

2005년 개선사업 이전에는 답압으로 인해 낙엽층이 소실되 었으며, 전체 8 개 조사구 중 2 개 조사구(조사구 1 , 조사구 7)에 서만 유기물층이 $1.0 \mathrm{~cm}$ 로 조사되었다. 개선사업 후 2010년에는 답압에 대한 피해가 줄어서 낙엽층이 최대 $3.0 \mathrm{~cm}$ 까지 새로 형 성되었고, 유기물층의 깊이도 $1.5 \sim 8.0 \mathrm{~cm}$ 로 증가하였다. 특히 조사구 1과 조사구 7은 2005년에는 답압 영향으로 인해 낙엽층 이 소실되어 있었으며, 유기물층이 $1.0 \mathrm{~cm}$ 로 식물이 생육하는데 적합하지 않았다. 2010년에는 소나무림 식재지에 울타리를 설 치하고, 초화류를 식재하여 접근이 제한되면서 답압에 대한 피

표 2. 강북구 솔밭근린공원 토양경도 변화

\begin{tabular}{|c|c|c|c|c|c|c|}
\hline \multirow{2}{*}{ 구분 } & \multicolumn{3}{|c|}{ 2005년 } & \multicolumn{3}{|c|}{ 2010년 } \\
\hline & 토양경도 $\left(\mathrm{kg} / \mathrm{cm}^{2}\right)$ & 면적 $\left(\mathrm{m}^{2}\right)$ & 비율(\%) & 토양경도 $\left(\mathrm{kg} / \mathrm{cm}^{2}\right)$ & 면적 $\left(\mathrm{m}^{2}\right)$ & 비율(\%) \\
\hline \multirow{6}{*}{$\begin{array}{l}\text { 소나무림 } \\
\text { (이용지역) }\end{array}$} & $15 \sim 30$ & 5,633 & 25.8 & - & - & - \\
\hline & $30 \sim 50$ & 5,333 & 24.4 & - & - & - \\
\hline & $50 \sim 70$ & 5,627 & 25.8 & - & - & - \\
\hline & $70 \sim 100$ & 1,593 & 7.3 & - & - & - \\
\hline & $100 \sim 130$ & 79 & 0.4 & - & - & - \\
\hline & 평균(54.8) & 18,265 & 83.7 & - & - & - \\
\hline \multirow{3}{*}{$\begin{array}{c}\text { 소나무림 } \\
\text { (높이 } 50 \mathrm{~cm} \text { 이상 경계석) }\end{array}$} & $10 \sim 15$ & 666 & 3.1 & - & - & - \\
\hline & $15 \sim 30$ & 197 & 0.9 & - & - & - \\
\hline & 평균(15.8) & 863 & 4.0 & - & - & - \\
\hline \multirow{4}{*}{$\begin{array}{c}\text { 소나무림 } \\
\text { (관목 및 초본식재지) }\end{array}$} & $0 \sim 5$ & 1,609 & 7.4 & $0 \sim 4$ & 21,438 & 93.6 \\
\hline & $5 \sim 10$ & 916 & 4.2 & $4 \sim 6$ & 630 & 2.9 \\
\hline & $10 \sim 15$ & 165 & 0.8 & $6 \sim 8$ & 552 & 2.5 \\
\hline & 평균(5.5) & 2,691 & 12.3 & 8 이상 & 199 & 1.0 \\
\hline 합계 & 평균(32.8) & 21,819 & 100.0 & 평균 $\left(4.0 \mathrm{~kg} / \mathrm{cm}^{2}\right)$ & 21,819 & 100.0 \\
\hline
\end{tabular}


표 3. 강북구 솔밭근린공원 토양단면구조 변화

(단위: $\mathrm{cm}$ )

\begin{tabular}{c|c|c|c|c}
\hline \multirow{2}{*}{ 구분 } & \multicolumn{2}{|c|}{ 2005년 } & \multicolumn{2}{c}{ 2010년 } \\
\cline { 2 - 5 } & 낙엽층 깊이 & 유기물층 깊이 & 낙엽층 깊이 & 유기물층 깊이 \\
\hline 조사구 1 & 0.0 & 1.0 & 3.0 & 3.0 \\
\hline 조사구 2 & 0.0 & 0.0 & 1.0 & 3.0 \\
\hline 조사구 3 & 0.0 & 0.0 & 0.5 & 2.5 \\
\hline 조사구 4 & 0.0 & 0.0 & 0.8 & 4.2 \\
\hline 조사구 5 & 0.0 & 0.0 & 2.0 & 8.0 \\
\hline 조사구 6 & 0.0 & 0.0 & 0.5 & 1.5 \\
\hline 조사구 7 & 0.0 & 1.0 & 1.0 & 5.0 \\
\hline 조사구 8 & 0.0 & 0.0 & 0.2 & 2.0 \\
\hline
\end{tabular}

해가 줄어 낙엽층이 $1.0 \sim 3.0 \mathrm{~cm}$ 까지 새로 형성되었고, 유기물 층의 깊이도 $3.0 \sim 5.0 \mathrm{~cm}$ 로 증가하였다(표 3 참조).

토양단면구조 분석 결과, 대부분 지역에서 공원 조성 및 개 선사업시 기존 지반층 위에 모래를 8.0 20.0cm 가량 성토하여 지면을 다진 것으로 판단되었으며, 유기물층의 증가는 소나무 하부에 다양한 야생초화류를 식재하면서 유기물비료를 추가로 투입하여 형성된 것으로 판단되었다. 소나무는 배수가 잘 되고 토양이 건조한 곳에서 생육이 양호하며(김진수 등, 1993), 연구 대상지는 모래를 성토하여 근계부 복토에 따른 통기성 불량, 세근 고사, 수세 저하를 방지하였다(김학범 등, 2003).

\section{3) 토양 이화학적 특성}

산림 생태계의 천이과정에서 소나무는 선구수종으로 비교적 척박한 토양조건에서도 잘 적응하는 것으로 알려져 있다. 소나 무의 생육에 적합한 토양은 일반적으로 중성이나 알칼리성보 다 $\mathrm{pH}$ 5.0 5.5 정도의 약산성 토양에서 양호한 성장을 보이며, 유기물함량, 치환성양이온 함량 등 양토가 적은 곳에 주로 분 포한다(송호경 등, 1997). 솔밭근린공원의 토양은 2005년에는 $\mathrm{pH}$ 5.76 6.70으로 약산성 토양에 가까우며, 퇴적층 유기물 함
량(4.42 10.55\%)과 유효인산(2.11 26.47mg/kg)이 미경작 산 림토양의 적정 기준치보다 대부분 높았으나, 소나무 생육 토양 환경 조건으로 큰 문제는 없는 것으로 판단되었다. 솔밭근린공 원 답압 피해 개선사업 사업 후 2010년 토양조사 결과, 조사구 1 성토층의 경우 토양산도는 $\mathrm{pH}$ 6.27에서 $\mathrm{pH} 5.09$ 로 약산성화 되었지만 소나무가 생장하는데는 문제가 없었다. 유기물 함량 은 $4.42 \%$ 에서 $20.76 \%$ 로 크게 증가하였으며, 이는 소나무 생장 이 불량해지는 $2 \%$ (한국수목보호연구센터, 2004)보다 높았다. 유기물함량 증가는 소나무 하층의 지피식물을 위해 지속적인 유기물비료의 시비가 있었기 때문으로 판단되었다. 치환성 양이 온은 각각 $\mathrm{K}^{+} 0.12 \mathrm{cmol} / \mathrm{kg}, \mathrm{Ca}^{++} 2.0 \mathrm{cmol} / \mathrm{kg}, \mathrm{Mg}^{++} 0.5 \mathrm{cmol} /$ $\mathrm{kg}$ 이하에서 소나무 생장이 불량해지고, $\mathrm{K}^{+} 0.18 \mathrm{cmol} / \mathrm{kg}, \mathrm{Ca}^{++}$ $2.5 \mathrm{cmol} / \mathrm{kg}, \mathrm{Mg}^{++} 1.0 \mathrm{cmol} / \mathrm{kg}$ 이상이면 생장에 양호하다(한국 수목보호연구센터, 2004). 조사구 1 성토층은 유효인산, 치환성 양이온이 전반적으로 증가하여 소나무 생장에 비교적 양호한 수준이었다. 조사구 6 성토층의 경우 토양산도는 $\mathrm{pH} 5.76$ 에서 $\mathrm{pH}$ 6.19로 변화되었지만 소나무가 생장하는데는 문제가 없었 다. 유기물 함량은 $6.81 \%$ 에서 $5.85 \%$ 로 다소 감소하였지만, 이 는 소나무 생장이 불량해지는 $2 \%$ (한국수목보호연구센터, 2004) 보다 높았다. 치환성양이온은 $\mathrm{K}^{+} 0.15 \mathrm{cmol} / \mathrm{kg}, \mathrm{Ca}^{++} 4.75 \mathrm{cmol} /$ $\mathrm{kg}, \mathrm{Mg}^{++} 0.48 \mathrm{cmol} / \mathrm{kg}$ 으로 비교적 소나무가 생장하기에 양호 한 수준이었다(표 4 참조).

이상의 토양 경도, 토양 구조 및 특성 변화를 살펴본 결과, 개선사업 이전 2005년에는 과도한 이용으로 인하여 경도가 높 아 식물생장에 영향이 있었고, 낙엽층과 유기물층이 형성되지 않아 소나무와 기타 식물생장에 영향이 있었을 것으로 판단되 었다. 개선사업 후 2010년에는 토양경도 감소와 낙엽층과 유기 물층의 생성, 유기물 함량의 전반적인 증가로 수목 생육 환경 이 개선된 것으로 판단되었다.

\section{3. 소나무 생육상태 변화}

표 4. 강북구 솔밭근린공원 식재구조 조사구별 토양 이화학적 특성 변화

\begin{tabular}{|c|c|c|c|c|c|c|c|c|c|c|c|}
\hline & \multirow{2}{*}{\multicolumn{2}{|c|}{ 조사구 }} & \multirow{2}{*}{$\begin{array}{c}\mathrm{pH} \\
\mathrm{W} 1: 5\end{array}$} & \multirow{2}{*}{$\begin{array}{c}\mathrm{EC} \\
\mathrm{dS} / \mathrm{m}\end{array}$} & \multirow{2}{*}{$\begin{array}{c}\text { O.M. } \\
\%\end{array}$} & \multirow{2}{*}{$\frac{\text { Avail.-P. }}{\mathrm{mg} / \mathrm{kg}}$} & $\mathrm{Ca}^{++}$ & $\mathrm{Mg}^{++}$ & $\mathrm{K}^{+}$ & $\mathrm{Na}^{+}$ & \multirow{2}{*}{ 토성 } \\
\hline & & & & & & & \multicolumn{4}{|c|}{$\mathrm{cmol} / \mathrm{kg}$} & \\
\hline \multirow{3}{*}{ 2005년 } & 1 & 성토층 & 6.27 & 0.02 & 4.42 & 2.11 & 0.06 & 0.16 & 0.39 & 0.07 & Loamy sand \\
\hline & \multirow{2}{*}{6} & 성토층 & 5.76 & 0.01 & 6.81 & 9.78 & 0.04 & 0.17 & 0.32 & 0.02 & Sand \\
\hline & & 퇴적층 & 6.12 & 0.02 & 10.55 & 26.47 & 0.10 & 0.50 & 0.42 & 0.07 & Loamy sand \\
\hline \multirow{4}{*}{ 2010년 } & \multirow{2}{*}{1} & 성토층 & 5.09 & 0.05 & 20.76 & 7.59 & 5.95 & 0.84 & 0.53 & 0.15 & Loamy sand \\
\hline & & 퇴적층 & 5.52 & 0.01 & 0.54 & 0.70 & 1.72 & 0.21 & 0.14 & 0.07 & Loamy sand \\
\hline & \multirow{2}{*}{6} & 성토층 & 6.19 & 0.02 & 5.85 & 4.21 & 4.75 & 0.48 & 0.15 & 0.08 & Loamy sand \\
\hline & & 퇴적층 & 6.26 & 0.01 & 0.61 & 1.75 & 2.51 & 0.23 & 0.14 & 0.07 & Sand \\
\hline \multirow{2}{*}{\multicolumn{2}{|c|}{ 선행연구 자료 }} & 밭토양(표토) & 5.80 & & 1.90 & 216.00 & 4.60 & 1.40 & 0.59 & & \\
\hline & & 미경작 산지토양 & 4.80 & & 6.40 & 5.60 & 2.27 & 0.70 & 0.25 & & \\
\hline
\end{tabular}

자료: 김계훈 등, 1995: 33-40 


\section{1) 가지생장량}

가지생장량 측정 소나무는 식재유형에 따라 총 15 주로 선정 하였으며, 공원관리사무소 옆 진입광장 주변의 소나무 2 주는 신규 식재된 소나무이었다(표 5 참조). 북서방향의 조사수목 2 , 3 은 흥고직경 22.0 32.5cm, 수고 $14 \mathrm{~m}$ 로 2005년 토양경도는 $4.6 \sim 15.8 \mathrm{~kg} / \mathrm{cm}^{2}$ 이었지만, 2010 년 토양경도는 $0.9 \sim 4.6 \mathrm{~kg} / \mathrm{cm}^{2}$ 이었다. 남서방향의 조사수목 $6,7,8$ 은 흥고직경 $25.2 \sim 32.5 \mathrm{~cm}$, 수고 4.5 12.0m로 2005년 토양경도는 53.5 $53.7 \mathrm{~kg} / \mathrm{cm}^{2}$ 이었지 만 2010년 토양경도는 $3.0 \mathrm{~kg} / \mathrm{cm}^{2}$ 이었다. 남향의 조사수목 9 는 흥고직경 $29.6 \mathrm{~cm}$, 수고 $8.0 \mathrm{~m}$ 로 2005년 토양경도는 $41.4 \mathrm{~kg} / \mathrm{cm}^{2}$ 이었지만, 2010 년 토양경도는 $6.7 \mathrm{~kg} / \mathrm{cm}^{2}$ 이었다. 동남방향의 조 사수목 $1,10,11,12,13,14,15$ 는 흥고직경 $11.7 \sim 42.8 \mathrm{~cm}$, 수고 6.0 14.5m로 2005년 토양경도는 $68.2 \sim 76.6 \mathrm{~kg} / \mathrm{cm}^{2}$ 이었지만, 2010 년 토양경도는 $2.1 \sim 3.2 \mathrm{~kg} / \mathrm{cm}^{2}$ 이었다. 중앙에 위치한 조사 수목 4, 5는 흥고직경 $39.0 \sim 50.5 \mathrm{~cm}$, 수고 $14.0 \sim 14.5 \mathrm{~m}$ 로 2005 년 토양경도는 $4.6 \sim 12.8 \mathrm{~kg} / \mathrm{cm}^{2}$ 이었지만, 2010년 토양경도는 $1.8 \sim 4.6 \mathrm{~kg} / \mathrm{cm}^{2}$ 이었다.

조사수목 1 은 개선사업 전 3 년과 개선사업 후 3 년의 가지생 장량을 비교하면 개선사업 전 3년(4년생, 5년생, 6 년생)간 가지 생장량은 138.2 187.8mm이었고, 개선사업 후 3년(1년생, 2년 생, 3년생)년간 가지생장량은 195.0 239.8mm이었다. 따라서 개선사업 후 3 년간 연간 가지생장량이 증가한 것으로 판단되었 다. 조사수목 5 는 개선사업 전 3 년과 개선사업 후 3 년의 가지생 장량을 비교하면 개선사업 전 3년(4년생, 5년생, 6년생)간 가지 생장량은 75.4 88.2mm이었고, 개선사업 후 3년(1년생, 2년생,
3년생)년간 가지생장량은 97.2 149.8mm이었다. 따라서 개선 사업 후 3년간 연간 가지생장량이 증가한 것으로 판단되었다. 조사수목 7은 남서방향에 위치한 수관이 발달한 수목으로 토양 경도 $53.7 \mathrm{~kg} / \mathrm{cm}^{2}$ (2005년)에서 $3.0 \mathrm{~kg} / \mathrm{cm}^{2}$ (2010년)로 변화된 지 역에 위치하였고, 현재까지 답압 피해가 지속되고 있는 산책로 (마사경화토 포장)에 있는 소나무이었다. 조사수목 7에 대해 개선사업 전 3년(4년생, 5년생, 6년생)간 가지생장량은 300.6 $330.8 \mathrm{~mm}$ 이었고, 개선사업 후 3 년(1년생, 2년생, 3년생)년간 가 지생장량은 197.2 258.8mm이었다. 조사수목 7은 대체로 연간 가지생장량이 감소하는 경향을 보였다. 조사수목 14 는 개선사 업 전 3년(4년생, 5년생, 6년생)간 가지생장량은 251.4 312.6mm 이었고, 개선사업 후 3 년(1년생, 2년생, 3년생)년간 가지생장량 은 359.2 405.6mm이었다. 따라서 개선사업 후 3년간 연간 가 지생장량이 증가한 것으로 판단되었다.

2005년과 2010년의 가지생장량을 비교·분석 결과, 조사수 목 7, 9는 현재까지 답압 피해가 지속되고 있는 산책로(마사경 화토 포장)에 있는 소나무로서 감소하는 생장량 변화를 나타냈 고, 조사수목 $3,13,15$ 는 공원 내 시설지 및 이용 동선과 인접 하여 지속적인 생육의 영향을 받고 있는 것으로 판단되었다. 조사수목 $1,2,4,5,6,8,10,11,12,14$ 에서는 개선사업 후의 가 지생장량이 점차 증가하는 생장량 변화를 나타내고 있었다.

개선사업 전과 후에 따라 소나무의 가지생장량에 어떠한 차 이가 있는지를 검증하기 위해 개선사업 전과 개선사업 후로 나 누어 대응표본 $T$-test를 실시하였다(표 6 참조). 가지생장량 개선사업 전과 후 가지생장량 평균 $T$-검정 결과 유의수준

표 5. 강북구 솔밭근린공원 조사수목 평균 가지생장량 변화

(단위: $\mathrm{mm}$ )

\begin{tabular}{|c|c|c|c|c|c|c|c|}
\hline \multirow{2}{*}{ 수목번호 } & \multicolumn{3}{|c|}{ 개선사업 후 } & \multicolumn{3}{|c|}{ 개선사업 전 } & \multirow{2}{*}{ 변화상 } \\
\hline & 1년생 & 2년생 & 3년생 & 4년생 & 5년생 & 6년생 & \\
\hline 조사수목 1 & 239.8 & 205.4 & 195.0 & 187.8 & 156.6 & 138.2 & $\triangle$ \\
\hline 조사수목 2 & 158.8 & 124.8 & 136.0 & 96.4 & 108.6 & 89.8 & $\Delta$ \\
\hline 조사수목 3 & 108.0 & 101.0 & 112.0 & 116.0 & 131.0 & 115.0 & - \\
\hline 조사수목 4 & 135.8 & 132.4 & 127.8 & 89.8 & 119.0 & 118.2 & $\triangle$ \\
\hline 조사수목 5 & 149.8 & 102.4 & 97.2 & 88.2 & 81.2 & 75.4 & $\triangle$ \\
\hline 조사수목 6 & 169.0 & 193.2 & 161.8 & 152.2 & 174.6 & 189.6 & $\triangle$ \\
\hline 조사수목 7 & 197.2 & 208.6 & 258.8 & 305.2 & 330.8 & 300.6 & $\nabla$ \\
\hline 조사수목 8 & 201.0 & 189.6 & 183.6 & 137.0 & 136.6 & 180.4 & $\triangle$ \\
\hline 조사수목 9 & 69.2 & 104.8 & 96.6 & 91.4 & 106.2 & 119.6 & $\nabla$ \\
\hline 조사수목 10 & 165.2 & 127.6 & 119.8 & 113.8 & 111.2 & 138.4 & $\triangle$ \\
\hline 조사수목 11 & 235.4 & 166.6 & 100.4 & 98.8 & 71.0 & 81.0 & $\triangle$ \\
\hline 조사수목 12 & 245.4 & 184.2 & 126.0 & 94.6 & 53.0 & 113.0 & $\triangle$ \\
\hline 조사수목 13 & 97.6 & 77.0 & 85.4 & 88.2 & 99.8 & 138.2 & - \\
\hline 조사수목 14 & 405.6 & 390.2 & 359.2 & 312.6 & 256.0 & 251.4 & $\triangle$ \\
\hline 조사수목 15 & 235.6 & 201.0 & 243.0 & 235.4 & 219.2 & 236.4 & - \\
\hline
\end{tabular}

$\triangle:$ 증가하는 경향, $\nabla:$ 감소하는 경향, $-:$ 유사한 경향 
표 6. 강북구 솔밭근린공원 소나무 가지생장량 대응표본 T-검정

\begin{tabular}{|c|c|c|c|c|c|c|c|c|}
\hline \multicolumn{3}{|c|}{ 구분 } & \multirow{2}{*}{$\begin{array}{c}\text { 평균 } \\
147.72 \\
\end{array}$} & \multirow{2}{*}{\multicolumn{2}{|c|}{$\begin{array}{c}\text { 빈도 } \\
75 \\
\end{array}$}} & \multirow{2}{*}{\multicolumn{2}{|c|}{$\frac{\text { 표준편차 }}{82.082}$}} & \multirow{2}{*}{$\frac{\text { 평균의 표준오차 }}{9.478}$} \\
\hline \multirow{2}{*}{ 가지생장량 } & \multicolumn{2}{|c|}{ 개선사업 전 평균 } & & & & & & \\
\hline & \multicolumn{2}{|c|}{ 개선사업 후 평균 } & 171.66 & & 75 & \multicolumn{2}{|c|}{84.704} & 9.781 \\
\hline \multirow{3}{*}{ 변수 } & \multicolumn{5}{|c|}{ 대응차 } & \multirow{3}{*}{$t$} & \multirow{3}{*}{ 자유도 } & \multirow{3}{*}{ 유의확률 (양쪽) } \\
\hline & \multirow{2}{*}{ 평균 } & \multirow{2}{*}{ 표준편차 } & \multirow{2}{*}{ 평균의 표준오차 } & 차이의 & 신뢰구간 & & & \\
\hline & & & & 하한 & 상한 & & & \\
\hline 가지생장량 & 23.942 & 59.788 & 6.904 & 10.186 & 37.698 & 3.468 & 74 & 0.001 \\
\hline
\end{tabular}

(0.05)에서 통계적으로 고도의 유의성이 인정되었다. 즉, 개선 사업 전과 후 가지생장량의 평균 차이가 있다는 결론이 도출되 어, 솔밭근린공원 답압 피해지역의 개선사업은 개선사업 후 소 나무 가지생장량 증가에 효과가 있는 것으로 나타났다.

\section{2) 직경생장량}

2007년 개선사업 전과 후의 소나무 생장량 변화를 분석하기 위하여 7개의 대표 조사구를 설정하였다. 대표 조사구는 과거 솔밭공원의 토양경도 조사 결과를 바탕으로 7 개 등급으로 구분 하였다. 그리고 각 등급별로 소나무 10 주를 선정하여 총 70 주 의 직경생장량을 측정하였다. 조사수목의 흥고직경은 20.0 $45.0 \mathrm{~cm}$ 이었고, 수고는 $7.0 \sim 19.0 \mathrm{~m}$ 이었다(표 7 참조).

조사구 1은 토양경도 $7.2 \mathrm{~kg} / \mathrm{cm}^{2}$ (2005년)에서 $0.9 \mathrm{~kg} / \mathrm{cm}^{2}(2010$ 년)로 변화된 지역으로 조사수목 1-2, 1-3, 1-5, 1-6, 1-7, 1-8에 서 2007년 개선사업 후에 개선사업 전보다 증가한 것으로 분석 되었다. 조사구 2 는 토양경도 $12.8 \mathrm{~kg} / \mathrm{cm}^{2}$ (2005년)에서 $1.8 \mathrm{~kg} /$ $\mathrm{cm}^{2}$ (2010년)로 변화된 지역으로 조사수목 2-2, 2-3, 2-4, 2-5, 2-6, 2-8, 2-9, 2-10에서 2007년 개선사업 후에 개선사업 전보 다 증가한 것으로 분석되었다. 조사구 3 은 토양경도 $15.8 \mathrm{~kg} /$ $\mathrm{cm}^{2}$ (2005년)에서 $2.1 \mathrm{~kg} / \mathrm{cm}^{2}$ (2010년)로 변화된 지역으로 조사 수목 3-1, 3-2, 3-6, 3-7, 3-8, 3-9, 3-10에서 2007년 개선사업 후에 개선사업 전보다 증가한 것으로 분석되었다. 조사구 4 는 토양경도 $43.1 \mathrm{~kg} / \mathrm{cm}^{2}\left(2005\right.$ 년)에서 $3.7 \mathrm{~kg} / \mathrm{cm}^{2}(2010$ 년)로 변화 된 지역으로 조사수목 4-1, 4-2, 4-3, 4-6, 4-7, 4-8, 4-9에서 2007 년 개선사업 후에 개선사업 전보다 증가한 것으로 분석되
었다. 조사구 5 는 토양경도 $53.5 \mathrm{~kg} / \mathrm{cm}^{2}\left(2005\right.$ 년)에서 $3.0 \mathrm{~kg} / \mathrm{cm}^{2}$ (2010년)로 변화된 지역으로 조사수목 5-1, 5-3, 5-5, 5-6, 5-7, 5-8, 5-10에서 2007년 개선사업 후에 개선사업 전보다 증가한 것으로 분석되었다. 조사구 6 은 토양경도 $76.6 \mathrm{~kg} / \mathrm{cm}^{2}(2005$ 년 $)$ 에서 $3.2 \mathrm{~kg} / \mathrm{cm}^{2}$ (2010년)로 변화된 지역으로 조사수목 6-1, 6-2, $6-4,6-5,6-8,6-9,6-10$ 에서 2007년 개선사업 후에 개선사업 전보다 증가한 것으로 분석되었다. 조사구 7 은 토양경도 $130.4 \mathrm{~kg} /$ $\mathrm{cm}^{2}$ (2005년)에서 $1.6 \mathrm{~kg} / \mathrm{cm}^{2}(2010$ 년)로 변화된 지역으로 조사 수목 7-1, 7-3, 7-4, 7-5, 7-6, 7-10에서 2007년 개선사업 후에 개선사업 전보다 증가한 것으로 분석되었다.

조사구별 평균 직경생장량 변화를 분석한 결과, 조사구 1 은

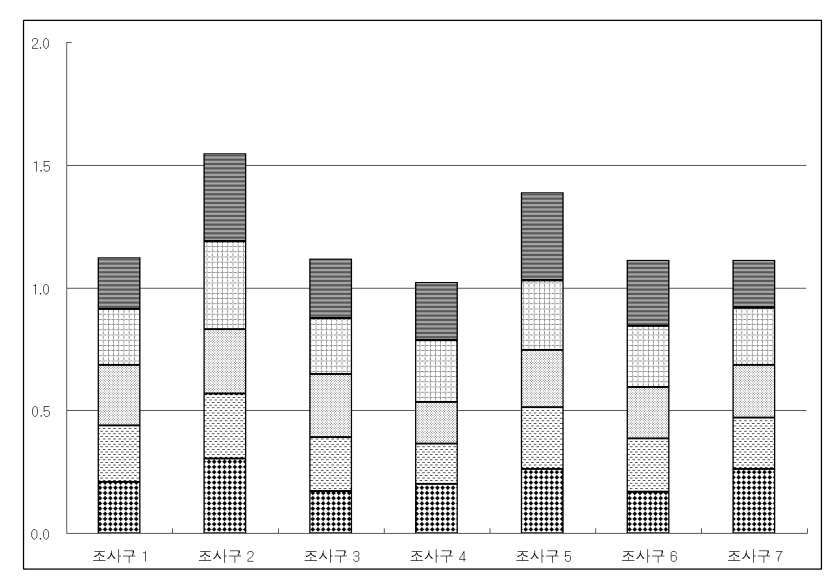

그림 5. 강북구 솔밭근린공원 조사구별 평균 직경생장량 변화

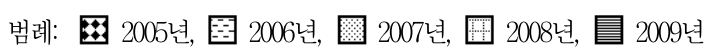

표 7. 강북구 솔밭근린공원 소나무 조사구별 평균 직경생장량 변화

(단위: $\mathrm{cm}$ )

\begin{tabular}{c|c|c|c|c|c|c}
\hline 구분 & 토양경도 $\left(\mathrm{kg} / \mathrm{cm}^{2}\right) *$ & 2005년 & 2006년 & 2007년 & 2008년 & 2009년 \\
\hline 조사구 1 & $0 \sim 10$ & 0.21 & 0.23 & 0.25 & 0.23 & 0.21 \\
\hline 조사구 2 & $10 \sim 15$ & 0.30 & 0.26 & 0.26 & 0.36 & 0.36 \\
\hline 조사구 3 & $15 \sim 30$ & 0.17 & 0.22 & 0.26 & 0.23 & 0.24 \\
\hline 조사구 4 & $30 \sim 50$ & 0.20 & 0.16 & 0.17 & 0.25 & 0.23 \\
\hline 조사구 5 & $50 \sim 70$ & 0.26 & 0.25 & 0.23 & 0.28 & 0.36 \\
\hline 조사구 6 & $70 ~ 100$ & 0.17 & 0.22 & 0.21 & 0.25 & 0.27 \\
\hline 조사구 7 & $100 ~ 140$ & 0.26 & 0.21 & 0.22 & 0.23 & 0.19 \\
\hline
\end{tabular}

*: 2005년 토양경도 조사결과 
표 8. 강북구 솔밭근린공원 소나무 직경생장량 대응표본 $T$-검정

\begin{tabular}{|c|c|c|c|c|c|c|c|c|}
\hline \multicolumn{3}{|c|}{ 구분 } & 평균 & \multicolumn{2}{|c|}{ 빈도 } & \multicolumn{2}{|c|}{ 표준편차 } & 평균의 표준오차 \\
\hline \multirow{2}{*}{ 직경생장량 } & \multicolumn{2}{|c|}{ 개선사업 전 평균 } & 0.2242 & \multicolumn{2}{|c|}{70} & \multicolumn{2}{|c|}{0.10001} & 0.01195 \\
\hline & \multicolumn{2}{|c|}{ 개선사업 후 평균 } & 0.2639 & \multicolumn{2}{|r|}{70} & \multicolumn{2}{|c|}{0.13769} & 0.01646 \\
\hline \multirow{3}{*}{ 변수 } & \multicolumn{5}{|c|}{ 대응차 } & \multirow{3}{*}{$t$} & \multirow{3}{*}{ 자유도 } & \multirow{3}{*}{ 유의확률 (앙쪽) } \\
\hline & \multirow{2}{*}{ 평균 } & \multirow{2}{*}{ 표준편차 } & \multirow{2}{*}{ 평균의 표준오차 } & \multicolumn{2}{|c|}{ 차이의 95\% 신뢰구간 } & & & \\
\hline & & & & 하한 & 상한 & & & \\
\hline 직경생장량 & 0.03974 & 0.11352 & 0.01357 & 0.01267 & 0.06681 & 2.929 & 69 & 0.005 \\
\hline
\end{tabular}

2009년에 2005년과 같은 직경생장량을 보였으며, 조사구 2 6 은 증가하는 경향을 나타냈다. 조사구 7은 2005년에 비해 2009 년에 감소하는 것으로 분석되었으며, 이는 일부 조사수목의 직경생장량이 크게 감소되어 평균값의 오류를 나타낸 것으로 판단되었다. 강북구 솔밭근린공원의 토양경도는 2005 년에 최하 $7.2 \mathrm{~kg} / \mathrm{cm}^{2}$ 에서 최고 $76.6 \mathrm{~kg} / \mathrm{cm}^{2}$ 로 경도가 높아 식물생장에 영 향이 있었고, 2010년의 토양경도는 최하 $0.9 \mathrm{~kg} / \mathrm{cm}^{2}$ 에서 최고 $3.7 \mathrm{~kg} / \mathrm{cm}^{2}$ 로 경도가 크게 감소되어 수목생장이 유리한 환경으 로 개선됨에 따라 2005년과 2010년 직경생장량 비교 - 분석 결 과, 대부분 조사구에서 개선사업 후 직경생장량이 증가한 것으 로 판단되었다(그림 5 참조).

개선사업 전과 후에 따라 소나무의 직경생장량에 어떠한 차 이가 있는지를 검증하기 위해 개선사업 전과 후로 나누어 대응 표본 개선사업 전과 후에 따라 소나무의 직경생장량에 어떠한 차이가 있는지를 검증하기 위해 개선사업 전과 개선사업 후로 나누어 대응표본 $T$-test를 실시하였다(표 8 참조). 직경생장량 개선사업 전 · 후 직경생장량 평균 $\mathrm{T}$-검정 결과, 통계적으로 유 의수준 0.05 에서 유의성이 인정되었다. 즉 개선사업 전과 후 직 경생장량의 평균 차이가 있다는 결론이 도출되어, 솔밭근린공 원 답압 피해지역의 개선사업은 소나무 직경생장량 증가에 효 과가 있는 것으로 나타났다.

\section{IV. 결론}

본 연구에서는 서울시의 유일한 평지형 소나무림인 솔밭근 린공원의 답압 피해 개선사업의 효과를 검증하기 위해 개선사 업 사업 전과, 개선사업 사업 후 소나무림의 생육상태 및 토양 환경을 비교· 분석하였다.

첫째, 생태적 특성 변화를 검토하기 위해 소나무 식재유형, 식재구조를 분석하였다. 개선사업 전과 후 가장 큰 변화를 살 펴보면, 솔밭근린공원 전체면적 $34,752 \mathrm{~m}^{2}$ 중 하층 식생이 없는 소나무림(나지)이 감소하였으며, 소나무림(관목 및 초본식재 지)은 크게 증가하였다. 둘째, 토양구조 및 특성 분석을 위해 토양경도, 토양단면구조, 토양 이화학적 특성을 조사하였다. 2010 년 토양경도는 대부분 양호한 상태이었고, 울타리 설치와 초화
류 식재로 인해 토양경도 상태가 개선된 것으로 파악되었다. 토양단면구조 변화에서는 2005년 과거에는 답압 영향으로 인 해 낙엽층이 소실되어 있었으며, 유기물층이 식물이 생육하는 데 적합하지 않았다. 2010년에는 답압에 대한 피해가 줄어서 낙엽층이 새로 형성되었고, 유기물층의 깊이도 증가하였다. 토 양 이화학적 특성 변화에서는 2005년도 조사결과, 약산성 토양 에 가까우며, 퇴적층 유기물 함량과 유효인산이 미경작 산림토 양의 적정 기준치보다 높았으나, 소나무 생육 토양환경조건으 로 크게 문제는 없는 것으로 판단되었다. 셋째, 소나무 생육상 태를 비교 분석을 위해 가지생장량, 직경생장량을 측정하였다. 개선사업 후 솔밭근린공원의 소나무는 가지생장량 변화는 점 차 증가하는 경향을 보였으며, 생장량 변화를 살펴본 결과, 대 부분의 조사구에서 소나무 3 8주가 다시 생육이 양호해지는 것을 확인할 수 있었다. 이는 답압 피해로 인해 악화되었던 소 나무 생육상태가 개선된 것으로, 2007년 답압 피해지역 개선사 업 효과를 확인하였다.

개선사업 전과 후에 따라 소나무의 가지생장량과 직경생장 량에 어떠한 차이가 있는지를 검증하기 위해 대응표본 $T$-test 를 실시하였다. 가지생장량은 유의한 결과가 도출되었으며, 소 나무 가지생장량에 있어 전체 조사구는 개선사업 전과 후 평균 차이가 있었다. 직경생장량은 유의한 결과가 도출되었으며, 개 선사업 전과 후 소나무 직경생장량에 있어 전체 조사구는 개선 사업 전과 후 평균 차이가 있었다.

연구 한계로는 대상지내에서만 소나무 가지생장량 및 직경 생장량의 비교를 시행하여 실제 개선사업에 의한 효과를 검증 하는데 어려움이 있었다. 추후 솔밭근린공원과 인접한 답압 피 해를 받지 않은 북한산 소나무 군락 내에서 비교 대상을 선정 하여 비교분석하는 것이 필요할 것으로 판단되었다. 또한 생육 상태에 영향을 끼치는 시비량을 설계치와 현장 시비량을 정확 히 도출할 수 없었다. 가지생장량 조사 수목에서 생육환경이 좋아진 수목에서도 감소된 생장량 변화를 확인하기 위해 뿌리 잘림, 병충해 등의 여러 가지 다른 요인에 대한 고려가 이루어 지지 않았다. 향후 도시공원의 수목 답압 피해 지역의 개선사 업은 세부적인 연구가 지속적으로 필요하고, 답압에 의한 생육 상태 변화에 대한 연구가 보완되어야 할 것이다. 


\section{인용문헌}

1. 강북구(2005) 소나무림의 생태적 보존 및 친환경 이용관리 방안 연구. 강북구청. pp. $51-81$.

2. 김계훈, 윤주용, 류순호(1995) 한국토양 중 Cs-137과 K-40의 분포. 한국 토양비료학회지 28(1): 33-40.

3. 김용식, 김강두, 김동엽, 변무석, 송근준, 신현탁, 안영희, 오구균, 이경재, 이유미, 임동옥, 전승훈, 최송현, 한봉호(2006) 최신 조경식물학. 서울: 광일문화사. pp. 511.

4. 김진수, 이석우, 황재우, 권기원(1993) 금강소나무: 유전적으로 별개의 품종으로 인정될 수 있는가? 한국임학회지 82(2): 166-175.

5. 김태호(2003) 한라산과 다랑쉬오름 등산로의 답압에 의한 토양 압밀현 상. 한국지역지리학회지 9(2): 169-179.

6. 김학범, 장동수, 이승제(2003) 한국 마을술 관리 개선방안 연구. 한국정 원학회지 21(4): 90-99.

7. 농업과학기술원(2000) 토양 및 식물체분석법. 농업진흥청 농업과학기술 원. pp. 176.

8. 대한주택공사 주택연구소(2000) 임해매립지 식재지반 조성에 관한 사례 조사 연구. 대한주택공사. pp. 146.

9. 박인협(1985) 백운산지역 천연림생태계의 삼림구조 및 물질생산에 관한 연구. 서울대학교 대학원 박사학위논문.

10. 송호경, 장규관, 오동훈(1997) 우리 나라 서해안 지역의 곰솔나무림의 생태학적 연구. 농업과학연구 24(1): 11-15.

11. 오광인, 정남철(1998) 무등산 도립공원 내 자연휴식연제 구역의 등산로 훼손과 토양환경변화의 연구: 용추계곡과 평두메계곡을 중심으로. 농업 과학기술연구 33: 83-98.

12. 이도형(2004) 토양 산성화에 따른 소나무(Pinus densifora Sieb. et Zucc.) 의 뿌리 적응성에 관한 연구. 한국임학회지 93(1): 50-58.

13. 이상태, 윤석락, 박은희, 김종갑, 정영관(2005) 경북 지역 소나무의 연륜 생태학적 특성에 관한 연구. 한국농림기상학회지 7(4): 289-295.
14. 이수동, 이경재, 최진우(2009) 서울시 소나무림의 생태적 특성에 따른 관리방안 연구. 한국환경생태학회지 23(3): 258-271.

15. 이승우(2005) 도시녹지에서 발생하는 토양장해와 관리대책. 한국수목보 호연구회 2005(1): 41-48.

16. 이승우, 이충화, 이윤영, 정용호(2008) 산림토양 산성화가 소나무 생장 및 토양생물 활성에 미치는 영향. 한국토양비료학회. 포스터 발표. pp. 141.

17. 이우철, 이철환(1989) 한국산 소나무림의 식물사회학적 연구. 한국생태 학회지 12(4): 257-284.

18. 이창석(1993) 대기오염으로 교란된 여천공단 주변 소나무 군락의 재생. 한국생태학회지 16(3): 305-316.

19. 이창석, 길지현, 유영환(1998) 수도권 주변 소나무의 조직피해와 생장억 제. 한국생태학회지 21(2): 125-131.

20. 이창복(1980) 대한식물도감. 서울: 향문사. pp. 990

21. 이충화, 이승우, 진현오, 정진현, 이천용(2002) 소나무 묘목의 생장 및 영 양상태에 미치는 $\mathrm{Mn}$ 의 영향. 한국생태학회지 25(5): 349-352.

22. 임업연구원(1999) 소나무 소나무림. 임업연구원. pp. 205.

23. 정연숙(1998) 댐건설이 소나무의 연륜생장에 미치는 영향. 한국생태학회 지 21(3): 251-255.

24. 조현길, 서옥하, 최인화, 안태원(2011) 강원도 영서지역 소나무 마을솦의 생장환경과 관리방안. 한국환경생태학회지 25(6): 893-902.

25. 진현호, 방선희, 이충화, 김세영(2008) 토양산성화가 소나무, 상수리나무 묘목의 생장 및 영양상태에 미치는 영향. 한국임학회지 97(3): 266-273.

26. 최오길(2002) 등산객에 의한 답압이 설악산 아고산대에 자생하는 식물 의 분포에 미치는 영향. 강릉대학교 대학원 석사학위논문.

27. 한국수목보호연구센터(2004) 건강한 소나무림 보전 전략 수립 기초 연 구. 강릉시. pp. 595.

28. 吉剛邦二(1958) 日本松林 - 生態學的研究 - . 日本林業技術势會. pp. 198. 29. 日本土壤物理性測定法委員會(1972) 土壤物理性測定法. 養賢堂. 東京.

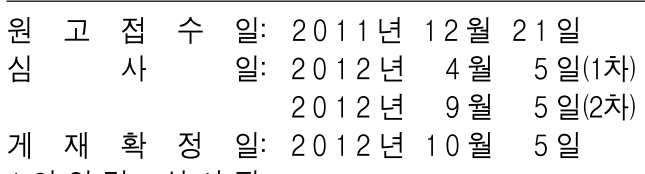

4 인 익 명 심 사필 